\title{
Biodegradation of Weathered Petroleum Hydrocarbons Using Organic Waste Amendments
}

\author{
Kimiya Yousefi $\mathbb{D}^{1},{ }^{1}$ Ali Mohebbi $\mathbb{D}^{1},{ }^{1}$ and John Pichtel $\mathbb{C}^{2}$ \\ ${ }^{1}$ Department of Chemical Engineering, Faculty of Enginnering, Shahid Bahonar University, Kerman, Iran \\ ${ }^{2}$ Environment, Geology and Natural Resources, Ball State University, Muncie, IN 47306, USA \\ Correspondence should be addressed to John Pichtel; jpichtel@bsu.edu
}

Received 1 December 2020; Revised 25 January 2021; Accepted 22 April 2021; Published 3 May 2021

Academic Editor: Rafael Clemente

Copyright $(92021$ Kimiya Yousefi et al. This is an open access article distributed under the Creative Commons Attribution License, which permits unrestricted use, distribution, and reproduction in any medium, provided the original work is properly cited.

Extraction, transport, and processing of petroleum products have resulted in inadvertent contamination of soil. Various technologies have been proposed for removal of petroleum hydrocarbon contaminants, including biological techniques. Treatment of aged (weathered) petroleum compounds is challenging, as these wastes tend to be enriched with recalcitrant hydrocarbons. The purpose of the reported study was to investigate remediation of weathered petroleum via simulated landfarming using selected soil amendments. Soil contaminated by aged crude petroleum from well fields in the southern Zagros region in Iran was treated in combination with plant compost, papermill sludge, activated carbon, and molasses. Over 15 weeks, the greatest percentage removal (40\%) of total petroleum hydrocarbons (TPH) occurred in the molasses treatment, followed by a $29 \%$ reduction in the plant compost treatment. The degradation constant $(\mathrm{k})$, produced by a kinetic model, demonstrated the performance of the molasses over the other treatments applied; experimental data adequately fitted into first-order kinetics $\left(k=0.005 \mathrm{~d}^{-1}, t^{1} / 2=71 \mathrm{~d}\right)$. Benzene decomposition was greatest (77 and $\left.74 \%\right)$ in the molasses and activated carbon treatments, respectively, and was lowest in the papermill sludge treatment (41\%). FTIR analysis revealed loss of benzene in all treatments. Bacterial counts were highest $\left(4.9 \times 10^{6} \mathrm{CFU} / \mathrm{g}\right)$ in the plant compost treatment and lowest $\left(1 \times 10^{5} \mathrm{CFU} / \mathrm{g}\right)$ in the untreated oilcontaminated soil. Based on the findings of the current study, it is possible to successfully conduct landfarming of aged petroleum deposits; however, it is recommended that common and inexpensive amendments such as molasses and plant compost be used when feasible.

\section{Introduction}

Petroleum hydrocarbons are a complex mixture of saturated hydrocarbons, aromatic compounds, asphaltenes, and resins [1]. Losses of petroleum occur during exploration activities, transportation and storage, and via accidental releases from petrochemical and other industries [2,3]. Data of quantities of petroleum released to land are often difficult to locate and compile. In the United States alone, pipeline accidents since 1986 have spilled an average of 76,000 barrels per year, or more than 3 million gallons [4].

Most components of crude petroleum are hazardous to human health and the environment [5]. In soil, the composition and dynamics of the native microbial community may be drastically altered due to petroleum pollution $[1,6]$.
A range of physical, chemical, and biological methods is available for remediation of petroleum-contaminated soil [7] including solvent extraction, chemical oxidation, phytoremediation, and bioremediation. Bioremediation relies upon the activities of indigenous microorganisms for contaminant degradation. This technology has been successfully applied for treatment of petroleum-contaminated sites, as all hydrocarbon components are ultimately biodegradable [8]. To accelerate cleanup efficiency at an affected site, soil can be excavated and applied to surface cells, where biological processes can be enhanced [8]. Such ex situ bioremediation, i.e., landfarming, has been documented to treat numerous hydrocarbon types including readily degradable carbon sources such as diesel fuel as well as certain recalcitrant compounds [7, 9]. Landfarming has been recognized as a 
feasible, environmentally friendly, and cost-effective technology for cleanup $[7,8]$.

Landfarming success is affected by several factors, including microbial types and numbers, soil organic matter content, types and amounts of clay minerals, temperature, water content, $\mathrm{pH}$, salinity, supply of oxygen, and concentrations of mineral nutrients $[10,11]$. The efficacy of landfarming is also affected by the type of petroleum compounds being treated; for example, weathered petroleum hydrocarbons are likely less amenable to landfarming as they contain a higher proportion of less degradable compounds [11].

The so-called biostimulation and bioaugmentation techniques improve the efficiency of landfarming [8]. Biostimulation refers to the activation of indigenous aerobic bacteria via addition of mineral nutrients and moisture $[7,8,12]$. Bioaugmentation involves inoculation of specific hydrocarbon-degrading bacteria to soil. In many cases, petroleum-contaminated soil is deficient in nutrients, enriched with other contaminants such as salts, and may have poor structure and water-holding capacity. Consequently, many soils are low in microbial diversity and abundance. In such scenarios, biostimulation and bioaugmentation can be successfully applied $[8,13]$. Several bioremediation strategies have been developed, but biostimulation is most commonly used [12].

Biostimulation and bioaugmentation can take place concurrently by amending contaminated soil with organic and inorganic materials [14-17]. For example, landfarming efficiency is enhanced at low cost by addition of plant compost, as it is a source of organic matter and diverse microbial populations. Plant compost has been useful for improving growth of horticultural crops [18], for treatment of soilborne pathogens [19], and for remediation of metalcontaminated soil [20]. According to Namkoong et al. [21], Adekunle [22], Chen et al. [23], and Wang et al. [8], addition of compost enhanced contaminant biodegradation efficiency. Utilization of paper mill sludge has been successful in treatment of soil contaminated by metals [24, 25]. Paper mill sludges are effective by virtue of a high organic matter content, as well as high concentration of basic cations. Composted paper mill sludge typically has high nitrogen content [26]. Other materials have been demonstrated effective for enhancing microbial activity and degradation of hydrocarbons. Al-Hadhrami et al. [27] and Boopathy and Manning [28] showed that addition of soluble organic carbon sources such as molasses was useful for biodegradation of oil-contaminated soil; their results were presumably a result of accelerated bacterial growth and concurrent cometabolic TPH degradation. The amendment of adsorbent materials such as activated carbon has potential for treatment of oil-contaminated soil. Activated carbon can cause rapid and irreversible immobilization of hydrocarbons, which may limit losses due to volatilization and leaching, thereby making TPH available for biodegradation $[11,29]$.

The purpose of the reported study was to evaluate the effects of common organic materials as landfarming amendments for weathered petroleum-contaminated soil.
The specific objective was to assess biostimulation and bioaugmentation by addition of plant compost, papermill sludge, molasses, and activated carbon. To our knowledge, this is one of the few tests of landfarming of aged petroleum wastes in arid regions.

\section{Materials and Methods}

2.1. Soil Collection and Preparation. Petroleum-contaminated soil was collected from the Sarvestan and Saadat Abad oil fields in the southern Zagros region of Fars Province, Iran $\left(29^{\circ} 16^{\prime} 73^{\prime \prime} \mathrm{N}, 53^{\circ} 8^{\prime} 37^{\prime \prime} \mathrm{E}\right)$. Noncontaminated soil was collected from the same region for use as an experimental control. Soil material was collected from the surface $0-30 \mathrm{~cm}$ and mixed thoroughly in the field. Large stones were removed, and the soil was placed into plastic bags in order to maintain moisture content. In the laboratory, soil material was ground with an agate mortar and pestle and sieved to pass a $2 \mathrm{~mm}$ mesh sieve.

2.2. Preparation of Treatments. $1 \mathrm{~kg}$ soil was added to each of 9-1 polyethylene containers. The oil-contaminated soil was mixed with an equal portion of noncontaminated soil in order to mimic typical large-scale landfarming operations. Soil treatments included plant compost, papermill sludge, activated carbon, and molasses (Table 1). The plant compost consisted of a mixture of moss and forest detritus which was composted for approximately two years. Papermill sludge was collected from the Kerman Paper paper mill in Kerman, Iran. Activated carbon was purchased from Rafsanjan Pars Active Carbon, Iran, and molasses was purchased from Marvdasht Sugar in Marvdasht, Iran. Rates of amendment application are shown in Table 1.

Treatments were incubated for 15 weeks in the laboratory at ambient temperature (approx. $22^{\circ} \mathrm{C}$ ). The soil in all treatments was mixed weekly using a stainless steel rod. Soil material was collected each week and allowed to air-dry for subsequent analysis.

2.3. Soil Physical and Chemical Analyses. Soil particle size distribution was determined using the hydrometer method [30]. Soil pH was determined with a Trans model BP3001 pH meter (Petro Centre, Singapore) on a $1: 10(\mathrm{w}: \mathrm{v})$ solids: deionized water slurry. Soil EC was measured using a $1: 10$ slurry using a Trans model BC3020 conductivity detector. Total nitrogen concentration (TC) was measured by the micro-Kjeldahl method [31] and soil extractable P by the Bray-1 method [32]. Total organic matter was determined using loss on ignition [33].

For analysis of total petroleum hydrocarbons (TPH), soil samples were extracted with a $1: 1(\mathrm{v} / \mathrm{v})$ mixture of acetone/ $n$-hexane according to Schwab et al. [34]. TPH concentration was measured in extracts with a Varian model CP-3800 gas chromatograph equipped with a flame ionization detector [35]. The system included a $1 \mu \mathrm{L}$ injection volume, 20 : 1 split ratio, inlet temperature of $250^{\circ} \mathrm{C}$, flow rate of $1 \mathrm{~mL} /$ min (helium), and a DB-5 $30 \mathrm{~m} \times 0.25 \mathrm{~mm} \times 0.25 \mu \mathrm{m}$ column. Initial column temperature of $40^{\circ} \mathrm{C}$ was held for $2 \mathrm{~min}$ 
TABle 1: Treatments applied to oil-contaminated soil, microcosm study.

\begin{tabular}{lcc}
\hline Abbreviation & Treatment & Ratio \\
\hline CON & Contaminated soil (control) ${ }^{1}$ & $1(\mathrm{~kg})$ \\
M & Contaminated soil + noncontaminated soil + molasses & $1: 1: 1(\mathrm{~kg})$ \\
C & Contaminated soil + noncontaminated soil + plant compost & $1: 1: 1(\mathrm{~kg})$ \\
PM & Contaminated soil + noncontaminated soil + papermill sludge & $1: 1: 1(\mathrm{~kg})$ \\
AC & Contaminated soil + noncontaminated soil + activated carbon & $1: 1: 0.50(\mathrm{~kg})$ \\
\hline
\end{tabular}

${ }^{1}$ Oil-contaminated soil with no amendments.

with a temperature ramp of $20^{\circ} \mathrm{C} / \mathrm{min}$, final temperature of $280^{\circ} \mathrm{C}$ held for $3 \mathrm{~min}$, solvent delay of $2 \mathrm{~min}$, MS scan of $40-300 \mathrm{~m} / z$, MS quad temperature of $150^{\circ} \mathrm{C}$, and an MS source temperature of $230^{\circ} \mathrm{C}$ [36].

Degradation rate of TPH was calculated as

$$
\text { Degradation }(\%)=\frac{C i-\mathrm{RC}}{\mathrm{C} i} \times 100,
$$

where $C i=$ initial content of contaminant (\%) and $\mathrm{RC}=$ residual content of contaminant (\%).

The following model for soil TPH concentration was used to determine the first-order decay rates for TPH in the microcosms:

$$
\begin{aligned}
& C e=C_{0} \exp (-k t) \\
& C_{0}=\mathrm{TPH} \text { concentration in soil sample before treat- } \\
& \text { ment }(\mathrm{mg} / \mathrm{kg}) \\
& C e=\mathrm{TPH} \text { concentration in soil after treatment }(\mathrm{mg} / \mathrm{kg}) \\
& k=\text { biodegradation rate constant }\left(\mathrm{day}^{-1}\right) \\
& t=\text { operational period (days) }
\end{aligned}
$$

Treatment efficiency (i.e., percent TPH removal) was determined using the difference between initial (day 0 ) and final (day 105) soil TPH concentrations in microcosms. The model estimated the biodegradation rate of hydrocarbons in soil relative to treatments applied. Half-life was then calculated using the following equation:

$$
\text { Half life }=\frac{\ln (2)}{k},
$$

where $k=$ the biodegradation rate constant $\left(\right.$ day $\left.^{-1}\right)$.

For FTIR analysis, soil samples were pressed into pellets using $\mathrm{KBr}$ in the ratio of $100: 1(100 \mathrm{mg} \mathrm{KBr}$ and $1 \mathrm{mg}$ sample), and spectra were recorded in the range of $400-4000 \mathrm{~cm}^{-1}$.There were there replicates of each sample.

2.4. Soil Microbiological Analysis. Populations of total culturable bacteria were determined for each treatment using the standard plate count method [37] on plate count agar (Peptone-yeast extract agar) on selected test dates. Colony forming units (CFU) from each treatment were counted after $48 \mathrm{~h}$ incubation at $30^{\circ} \mathrm{C}$.

2.5. Statistical Analysis. Data were analyzed using one-way ANOVA (Excel 2016); data were considered significantly different at $p<0.05$.

\section{Results and Discussion}

3.1. Soil and Amendment Characteristics. The initial $\mathrm{pH}$ of the nonamended soil was 7.65, and EC was $1.37 \mathrm{dS} / \mathrm{m}$ (Table 2). Soil N and P concentrations were 0.45 and $3.52 \%$, respectively. Soil texture was sandy clay loam. Soils in the southwest regions of Iran are primarily lithosols derived from igneous rocks.

All amendments were slightly to very alkaline; $\mathrm{pH}$ values were $9.8,8.8,8.2$, and 7.5 for the papermill sludge, activated carbon, plant compost, and molasses, respectively. The papermill sludge had the highest $\mathrm{N}$ concentration $(5.0 \%)$, and the plant compost had highest $\mathrm{P}$ concentration $(65 \mathrm{mg} /$ $\mathrm{kg}$ ). The $\mathrm{C}: \mathrm{N}$ ratios for the amendments were $6.7,51.8$, 131.5 , and 220.3 for the papermill sludge, molasses, compost, and activated carbon, respectively (Table 2 ).

3.2. Effect of Amendments on TPH Levels. TPH values for all treatments declined gradually over 15 weeks (Figures 1(a)1(d)). TPH concentrations at week 1 were 69,529, 60,153, and 50,556 , and $41,065 \mathrm{mg} / \mathrm{kg}$ for the molasses, papermill sludge, carbon, and compost treatments, respectively. By week 15, values declined to $42,865,41,767,38,898$, and $27,725 \mathrm{mg} / \mathrm{kg}$ for the papermill sludge, molasses, carbon, and compost treatments, respectively. Weekly TPH data for all the amended soils were significantly different $(p<0.05)$ from the control treatment.

Initial TPH values in the molasses treatment were $69,529 \mathrm{mg} / \mathrm{kg}$ which decreased to $41,767 \mathrm{mg} / \mathrm{kg}$ at week 15 (Figure 1(a)), a removal removal rate of $40 \%$. Molasses is enriched with various simple sugars (sucrose, glucose, and fructose); basic oxides (e.g., $\mathrm{K}_{2} \mathrm{O}, \mathrm{CaO}$, and $\mathrm{MgO}$ ); vitamins $\left(B_{1}, B_{2}\right.$, and $\left.B_{6}\right)$; and several acids [38] and, therefore, serves as a source of readily available nutrients for microorganisms [39]. Molasses is one of the most widely used soluble carbon substrates for bioremediation [40]; it has been applied successfully as a co-substrate in many biodegradation studies [41, 42]. Addition of molasses results in increased heterotrophic microbial populations and, thus, enhances TPH degradation rate. Tsai et al. [43] and Soleimani et al. [44] determined a TPH removal rate of $56 \%$ and $50 \%$ in microcosms with addition of $1000 \mathrm{mg} /$ $\mathrm{L}$ and $25000 \mathrm{mg} / \mathrm{kg}$ molasses, respectively. Lamichhane et al. [45] found that treatment of RDX-contaminated soil with dilute molasses was effective in enhancing RDX degradation, in part by increasing bacterial populations. Molasses injection at the Avco Lycoming Superfund site (USA) was successful in reducing concentrations of 
TABLE 2: Selected chemical characteristics of soil and amendments, mesocosm study.

\begin{tabular}{lccccc}
\hline Treatment & $\mathrm{pH}$ & $\mathrm{EC}(\mathrm{mS} / \mathrm{cm})$ & $C(\%)$ & $N(\%)$ & $\mathrm{Bray}-1 \mathrm{P}(\mathrm{mg} / \mathrm{kg})$ \\
\hline Papermill sludge & $9.80 \pm 0.29$ & $3.34 \pm 0.34$ & $33.36 \pm 2.28$ & $4.99 \pm 0.41$ & $6.05 \pm 0.35$ \\
Molasses & $7.46 \pm 0.31$ & $7.53 \pm 0.35$ & $89.17 \pm 1.34$ & $1.72 \pm 0.22$ & $4.50 \pm 0.23$ \\
Activated carbon & $8.82 \pm 0.34$ & $1.14 \pm 0.27$ & $85.46 \pm 2.05$ & $0.388 \pm 0.31$ & $5.91 \pm 0.25$ \\
Plant compost & $8.23 \pm 0.22$ & $3.88 \pm 0.26$ & $52.74 \pm 2.17$ & $0.401 \pm 0.12$ & $64.73 \pm 0.40$ \\
Noncontaminated soil & $7.65 \pm 0.16$ & $1.37 \pm 0.31$ & $0.69 \pm 0.34$ & $0.453 \pm 0.25$ & $3.52 \pm 0.36$ \\
Contaminated soil & $7.24 \pm 0.37$ & $5.23 \pm 0.29$ & $1.98 \pm 0.42$ & $0.06 \pm 0.02$ & $1.55 \pm 0.17$ \\
\hline
\end{tabular}

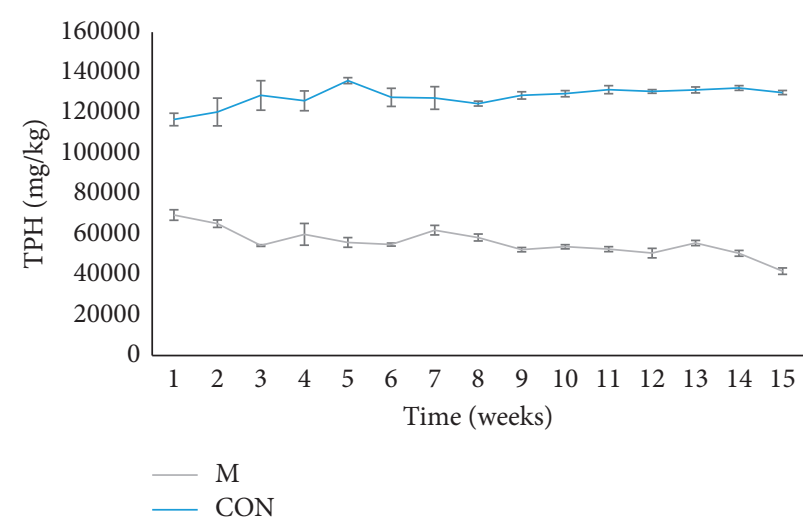

(a)

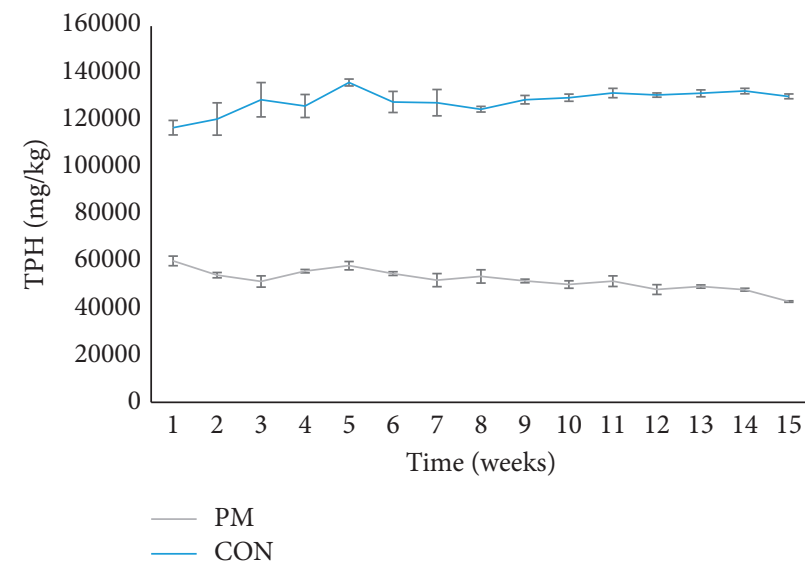

(c)

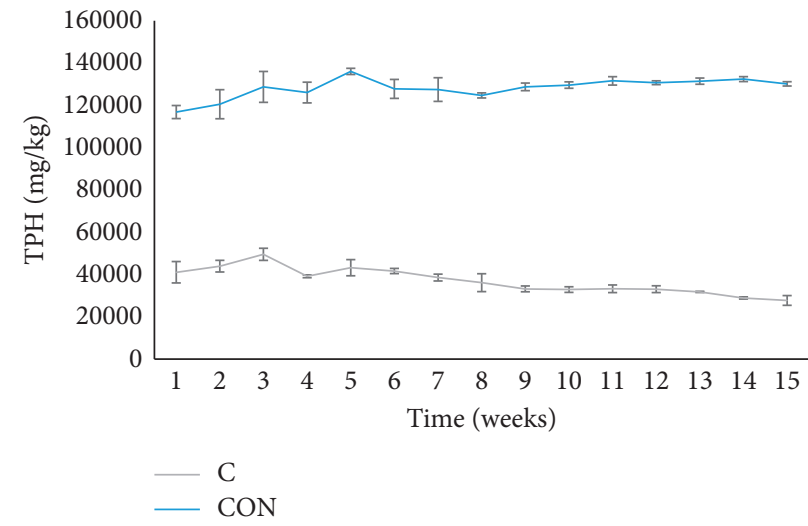

(b)

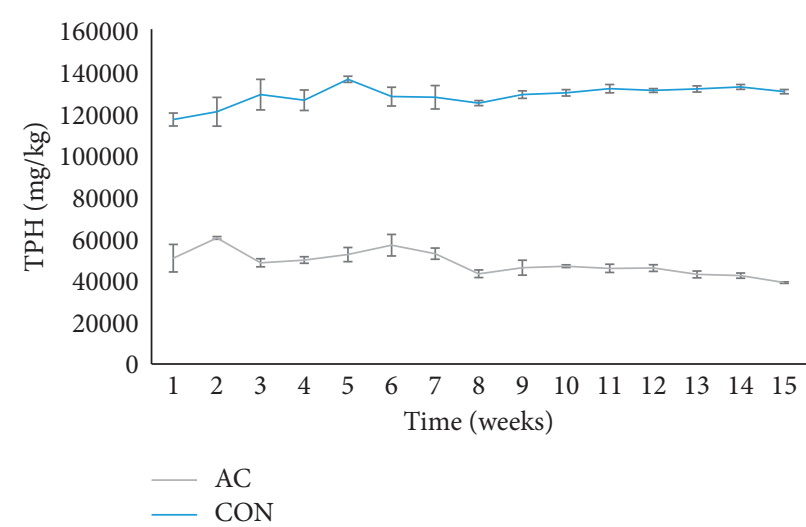

(d)

FIGURE 1: TPH disappearance from oil-contaminated soil as a function of amendment type; (a) molasses vs. control; (b) compost vs. control; (c) papermill sludge vs. control; and (d) activated carbon vs. control. M: molasses; C: plant compost; PM: papermill sludge; AC: activated carbon; and CON: control. All TPH data for the amended soils were significantly different $(p<0.05)$ from the control treatment at all sampling dates.

trichloroethene and 1,2-dichloroethene to below cleanup goals in many wells [46].

$\mathrm{TPH}$ concentration in the plant compost treatment was $41,065 \mathrm{mg} / \mathrm{kg}$ at week 1 , which declined to $27,725 \mathrm{mg} / \mathrm{kg}$ at week 15 (Figure 1(b)), a 32\% reduction. Plant compost provides nutrients, metabolizable carbon, and heterotrophic bacteria to soil while also increasing water-holding capacity [8]. It has been used successfully as a cosubstrate in many biodegradation studies [47, 48]. Adekunle [22] and Park et al. [48] showed that amendment of contaminated soil using plant compost resulted in TPH reductions from $40 \%$ to $75.9 \%$ and $98.4 \%$, respectively.
In the papermill sludge treatment, initial TPH values were $60,153 \mathrm{mg} / \mathrm{kg}$, which was followed by a gradual decline (Figure 1(c)). By week 14, TPH levels were $42,866 \mathrm{mg} / \mathrm{kg}$, a removal rate of $29 \%$. This modest rate of TPH reduction may be due to the high $\mathrm{pH}$ of the amendment (9.8) (Table 2); $\mathrm{pH}$ values in excess of 7.5 tend to convert soil $\mathrm{P}$ and micronutrients to less-available forms [49]. In remediation and reclamation projects, papermill sludge is known to provide benefits such as increased organic matter content, improved texture, and greater water-holding capacity. The main organic components in papermill sludge are wood and cellulose fibers of different lengths, lignin, and, to some extent, 
organic binders. These compounds are only slowly available to soil microbial consortia. The main inorganic components are kaolinite and calcium carbonate (as additives), as well as heavy metal impurities [50]. Composted papermill sludge is typically high in $\mathrm{N}$ content, which promotes microbial growth [51]. The total $\mathrm{N}$ content of the papermill sludge is $5.0 \%$, and the $\mathrm{C}: \mathrm{N}$ ratio was 6.7 (Table 2).

In the activated carbon treatment, initial TPH values were $50,556 \mathrm{mg} / \mathrm{kg}$, which declined to $38,898 \mathrm{mg} / \mathrm{kg}$ at week 14 (a 23\% overall reduction in TPH) (Figure 1(d)). Activated carbon has an extremely high specific surface area $\left(950 \mathrm{~m}^{2} /\right.$ g) and readily sorbs hydrocarbon contaminants [52]. Activated carbon can also alter soil microbial community structure and functioning [29]. Previous studies have shown that amendment of soils with adsorbent materials such as activated carbon may result in strong sorption of hydrocarbons, thus limiting biodegradation [11,29].

Percentage TPH removal and calculated first-order decay rates for each amendment appear in Table 3 . The calculated first-order decay rate for the molasses treatment was $0.005 \mathrm{day}^{-1}$. This was close to decay rates reported by Namkoong et al. [21]. Values for papermill sludge, plant compost, and activated carbon were $0.004,0.003$, and $0.002 \mathrm{day}^{-1}$, respectively. The attenuation half-life for the molasses treatment was 71 days. The longest half-life, 139 days, was calculated for the activated $\mathrm{C}$ treatment.

All amendments were effective in decreasing soil benzene concentrations (Table 4); concentrations after 15 weeks were significantly $(p<0.05)$ lower as compared to control.

Percent disappearance was $77,74,55$, and $41 \%$ for the molasses, activated carbon, plant compost, and papermill sludge treatments, respectively. This compares with a $21 \%$ decomposition in the control (Table 4). Substrate interactions are important in understanding the behavior of aromatic compounds in the environment [53]. Data for soil benzene loss in the molasses treatment corresponded with data for TPH decline (Figure 1(c)). In contrast, however, the carbon treatment resulted in low benzene concentrations, which was not reflected in TPH data (Figure 1(d)). It is possible that aromatic compounds may be preferentially sorbed by the carbon treatment [54].

In the oil-contaminated soil, a broad FTIR band at $3400 \mathrm{~cm}^{-1}$ is associated with H-bonded $\mathrm{OH}$ groups, including those of $\mathrm{COOH}$, and bands at 2925, 1460, and $1376 \mathrm{~cm}^{-1}$ indicate the presence of a mixture of hydrocarbons with varying chain lengths and $\mathrm{C}-\mathrm{H}$ branching vibrations within - $\mathrm{CH}$ - groups in the weathered oil (Figure 2). These bands are associated with long-chain aliphatic hydrocarbons such as hexadecane and eicosane $[55,56]$. The $1620 \mathrm{~cm}^{-1}$ band corresponds to aromatic ring C-C stretching and the presence of short-chain compounds containing carbonyl groups from esters, ketones, or acids. The band at $1116 \mathrm{~cm}^{-1}$ corresponds to $\mathrm{C}-\mathrm{C}-\mathrm{H}$ bending.

Substantial changes of hydrocarbon groups were detected in the amended oil-contaminated soil after 15 weeks (Figure 3). Less-intense bands occurred for many chemical groups in all treatments. In the molasses and compost treatments, bands were less intense at $2957-2850 \mathrm{~cm}^{-1}$ (bands related to $\mathrm{C}-\mathrm{H}$ vibrations). An intense band occurs at $1460 \mathrm{~cm}^{-1}$ in all treatments, especially molasses and
TABLE 3: Attenuation rate constant and attenuation half-life of TPH as calculated using the first-order model.

\begin{tabular}{lcc}
\hline Treatment & $\begin{array}{c}\text { Attenuation rate } \\
\text { constant }\left(\mathrm{day}^{-1}\right)\end{array}$ & $\begin{array}{c}\text { Attenuation half-life } \\
\text { (days) }\end{array}$ \\
\hline M & 0.005 & 71 \\
PM & 0.004 & 93 \\
C & 0.003 & 107 \\
AC & 0.002 & 139 \\
CON & -0.001 & - \\
\hline
\end{tabular}

TABLE 4: Soil benzene concentrations as a function of amendment, weeks 1 and 15 .

\begin{tabular}{lcc}
\hline Treatment & Week $1(\mathrm{mg} / \mathrm{kg})$ & Week $15(\mathrm{mg} / \mathrm{kg})$ \\
\hline Activated carbon & $455.42 \pm 95.16$ & $117.41 \pm 52.58^{*}$ \\
Papermill sludge & $448.34 \pm 23.11$ & $265.21 \pm 13.74^{*}$ \\
Plant compost & $375.41 \pm 38.33$ & $168.66 \pm 56.54^{*}$ \\
Molasses & $413.57 \pm 136.39$ & $96.21 \pm 38.83^{*}$ \\
Untreated soil & $432.82 \pm 140.54$ & $339.28 \pm 57.68$ \\
\hline
\end{tabular}

${ }^{*}$ Significant at $p<0.05$.

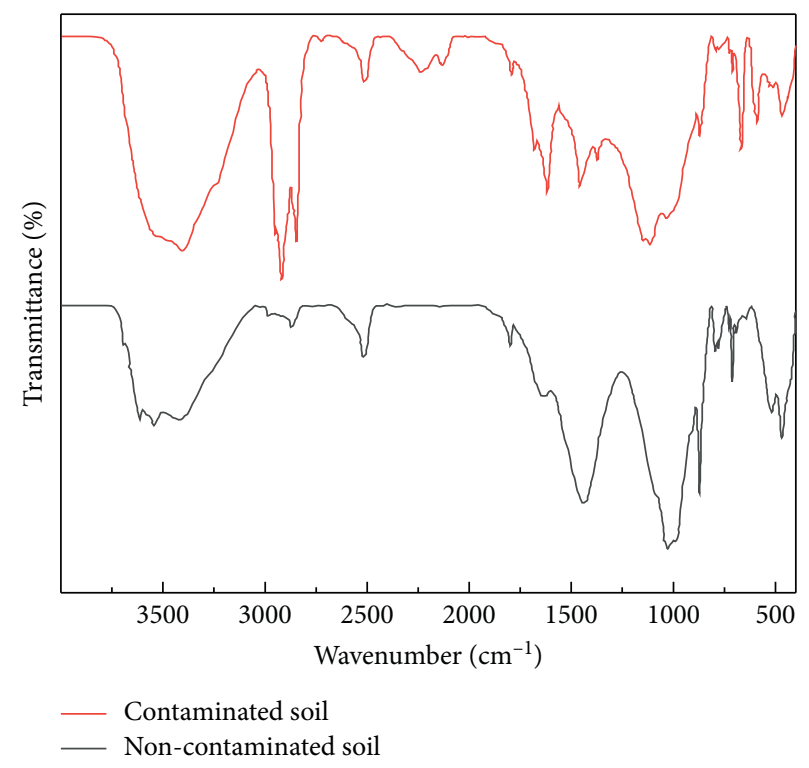

FIgURe 2: FTIR scans of oil-contaminated (red line) and noncontaminated soil (black line).

compost, and a small band at $1377 \mathrm{~cm}^{-1}$ in the molasses and carbon treatments; these may occur from a mixture of compounds having short chain lengths. An intense band occurs at $1780-1650 \mathrm{~cm}^{-1}$ in all treatments, but was more intense in the molasses treatment; this may correspond to new carbonyl-based compounds, possibly ketones, or aldehydes generated by microbial oxidation processes. Organic acids (i.e., sulfonate and phelonate) show bands in the range $600-1300 \mathrm{~cm}^{-1}$ and $1500-2000 \mathrm{~cm}^{-1}[57,58]$.

3.3. Soil pH, EC, and Nutrient Levels. At the initiation of the experiment, the papermill sludge treatment had the highest $\mathrm{pH}$ of all treatments (9.8) (Table 2). Papermill sludge 


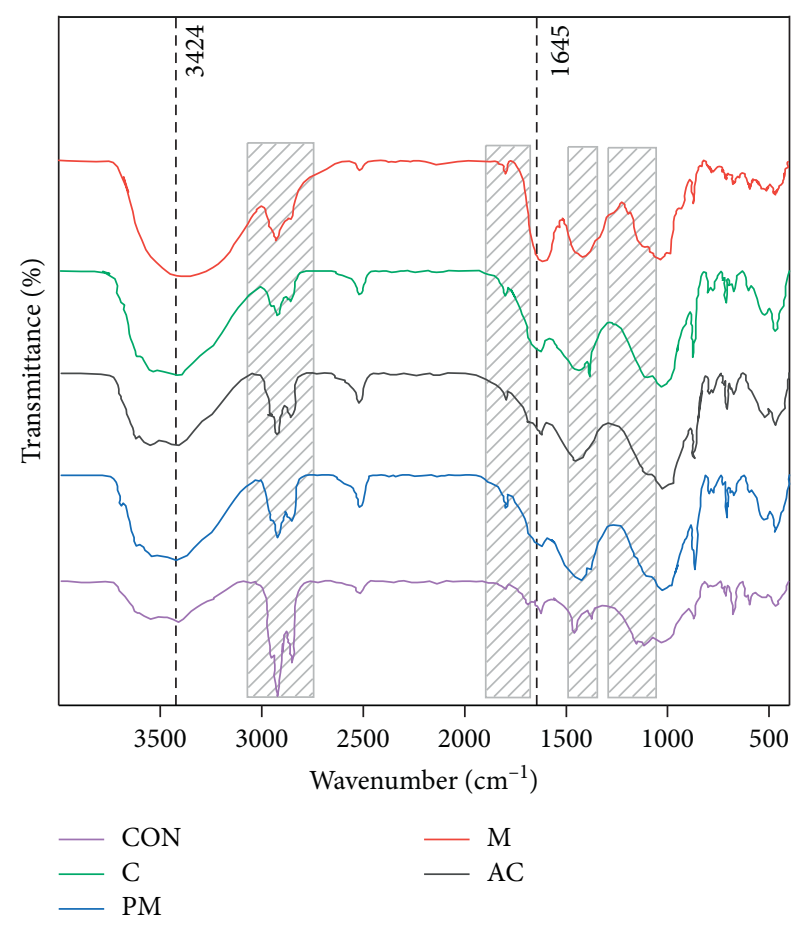

FIGURE 3: FTIR scans of soil in all treatments over 15 weeks.

typically has high $\mathrm{pH}$ values due to enrichment by basic cations such as Ca and $\mathrm{Mg}$ [59]. Kuokkanen et al. [50] measured a $\mathrm{pH}$ of 8.3 in papermill sludge and an EC of 0.2 $\mathrm{dS} / \mathrm{m}$. By virtue of its high $\mathrm{pH}$, papermill sludge is useful as a liming agent for acid soils [60]. The activated carbon had a $\mathrm{pH}$ of 8.82 (Table 2). Some chemically activated carbons have an acid $\mathrm{pH}$ after activation [61]; others, such as coconut-shell-based activated carbon, normally have a $\mathrm{pH}$ of 9-11 [62]. Plant compost $\mathrm{pH}$ was 8.23; this value is similar to those found for plant composts in a study by Tubeileh and Stephenson [19], where $\mathrm{pH}$ values ranged from 8.10 (crop residue compost) to 8.71 (grape pomace compost). Saengwilai et al. [20] measured pH 7.4 in plant-compost-amended soil. The molasses had the lowest $\mathrm{pH}$ (7.46) of all treatments (Table 2), yet was still in the alkaline range. Cane molasses typically has an acid $\mathrm{pH}$, usually between 5 and 7 , and salt content may be substantial (2-8\%) [63].

Soil $\mathrm{pH}$ is a critical factor for biodegradation as it impacts the activities of heterotrophic microbes and can alter community composition [64]. Soil pH, furthermore, influences the mobility of nutrients (e.g., P) and metals ranging from basic cations to transition metals. The ideal $\mathrm{pH}$ range for bacteria is generally between 6 and $8[11,65]$; soil pH values for all treatments were generally within this range (Figures 4(a)-4(d)). Despite fluctuations in $\mathrm{pH}$, there was an overall downward trend for all treatments during the first 4-6 weeks. This effect is presumably due to generation of organic acids during microbial metabolism of both the amendment material and components of the oily wastes $[66,67]$. For example, biological action on molasses results in the generation of acetic acid and other acids [68]. In the case of the control, $\mathrm{pH}$ values may have declined as a result of soil wetting, which may have leached some salts and bases
$\left(\mathrm{Na}^{+}, \mathrm{K}^{+}, \mathrm{Ca}^{2+}\right.$, and $\left.\mathrm{Mg}^{2+}\right)$, while simultaneously activating microbial populations which decompose native organic material and produce organic acids. By week 15, $\mathrm{pH}$ values of the treated soils returned close to initial readings (Figures 4(a) $-4(d)$ ).

Initial soil EC values for the treatments were 1.14, 1.37, $3.34,3.88$, and $7.53 \mathrm{mS} / \mathrm{cm}$ for the activated carbon, control, papermill sludge, compost, and molasses, respectively (Table 2). Values increased initially when the amendments were added (Figures 5(a)-5(d)), which may be the result of leaching of ions from amendments [10]. Following some fluctuation during weeks 2-10, EC values of many treatments were slightly lower by week 15 . EC data were significantly different $(p<0.05)$ among treatments for each sampling date of the study period. The overall downward trend in EC during incubation (Figures 5(a)-5(d)) may be due to microbial immobilization of certain basic cations (e.g., $\mathrm{K}^{+}, \mathrm{Ca}^{2+}$, and $\mathrm{Mg}^{2+}$ ) and anions $\left(\mathrm{NO}_{3}{ }^{-}\right)$. The peaks recorded during treatment are presumably the consequence of fertilizer $\left(\mathrm{KNO}_{3}\right)$ application. Salinity strongly affects soil microbial activity $[69,70]$ and, consequently, decomposition of hydrocarbons in contaminated soil [10]. It has been reported that salinity reduces microbial biomass [71].

Initial soil $\mathrm{N}$ concentrations (week 1) were significantly $(p<0.05)$ greater in the molasses and compost treatments compared to the papermill sludge and activated carbon treatments (Figure 6(a)). At weeks 6 and 15, the molasses, papermill sludge, and compost treatments had significantly greater $\mathrm{N}$ concentrations than did the activated carbon and the control. Nitrogen is critical for growth and proliferation of microbial cells [72], which are ultimately responsible for TPH degradation. Papermill sludge had the highest $\mathrm{N}$ content of all treatments (Table 2); however, in weeks 1, 6, and 14 relatively low soil $\mathrm{N}$ values were measured for this treatment (Figure 6(a)). When papermill sludge is composted, a substantial portion of the added $\mathrm{N}$ is rapidly immobilized by microbial biomass [26].

In weeks 1 and 6 , soil $\mathrm{P}$ concentrations in all treatments were significantly greater $(p<0.05)$ than the control, while in week 15, soil $\mathrm{P}$ was significantly greater in the compost and activated carbon treatments (Figure 6(b)). The compost treatment has about ten-fold greater $\mathrm{P}$ content than the other treatments $(65 \mathrm{mg} / \mathrm{kg}$ ) (Table 2). Phosphorus is essential for the production of nucleic acids, ATP, phospholipids, and other cellular structures [73]. Similar results are reported by Orji et al. [74] studying bioremediation of petroleum hydrocarbon in the laboratory and also by Ayotamuno et al. [72] and Odokuma and Dickson [75].

In weeks 1 and 6, organic carbon content in all treatments were significantly $(p<0.05)$ above the control (Figure 6(c)). At week 15, organic carbon levels were highest in the molasses treatment (Figure 6(c)). The molasses amendment had the highest carbon content of all the amendments (89.2\%) (Table 1). During incubation, soil organic carbon values decreased (Figure 6(c)). Molasses is a ready source of organic carbon [39], which is an appropriate media for bacterial attachment and growth [76]. By week 15, soil carbon levels in all treatments were significantly lower than those from week 1, suggesting loss of soil carbon via 


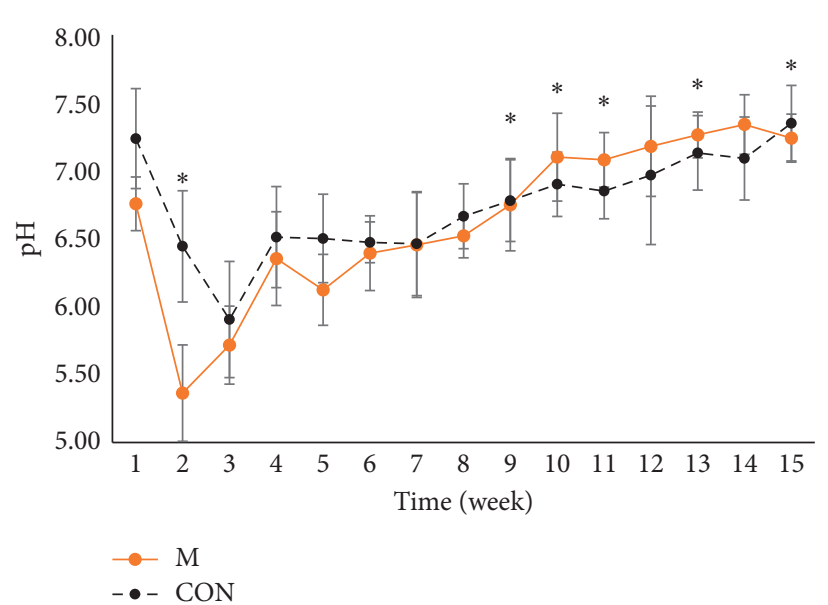

(a)

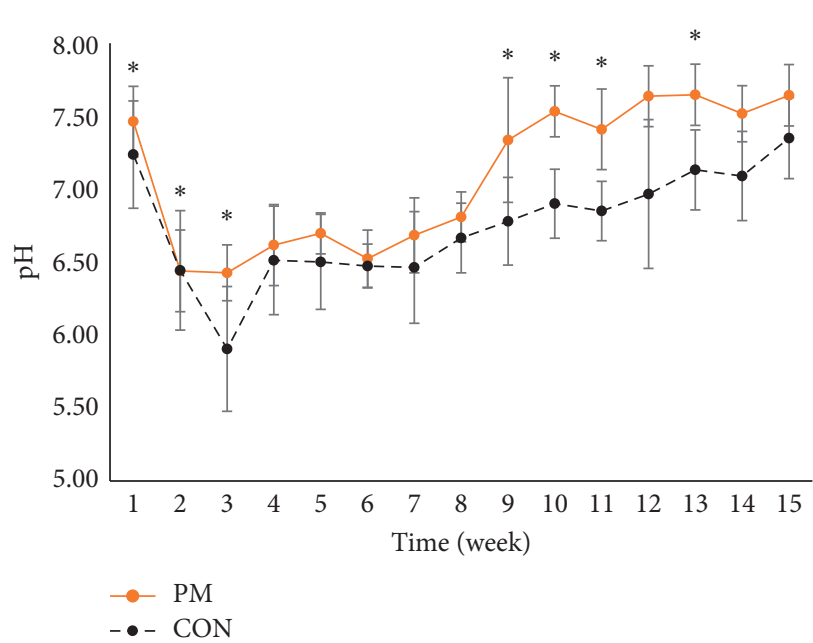

(c)

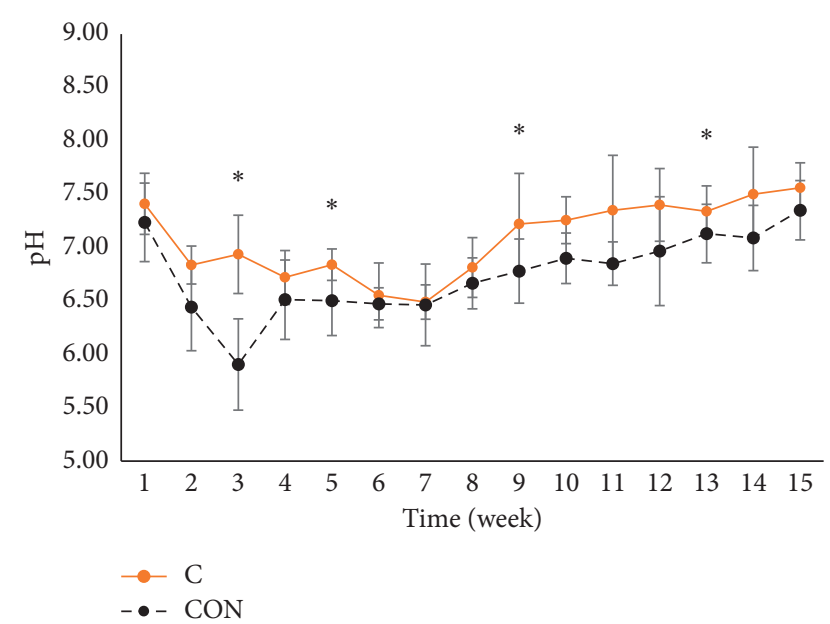

(b)

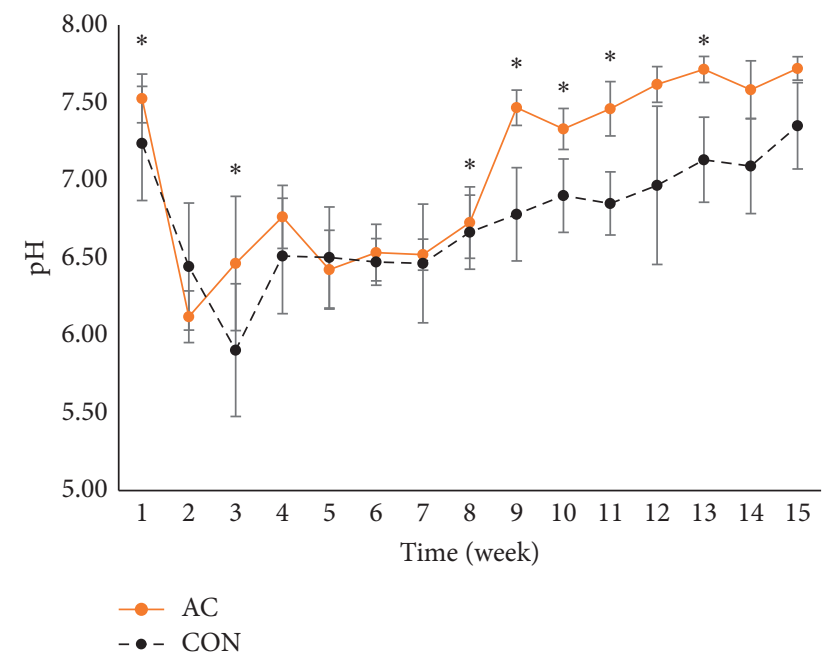

(d)

FIGURE 4: Soil pH values over 15 weeks of treatment; (a) molasses vs. control; (b) compost vs. control; (c) papermill sludge vs. control; and (d) activated carbon vs. control. M: molasses; C: plant compost; PM: papermill sludge; AC: activated carbon; and CON: control. $(*)$ indicates that data for the treatment were significantly different $(p<0.05)$ from the control.

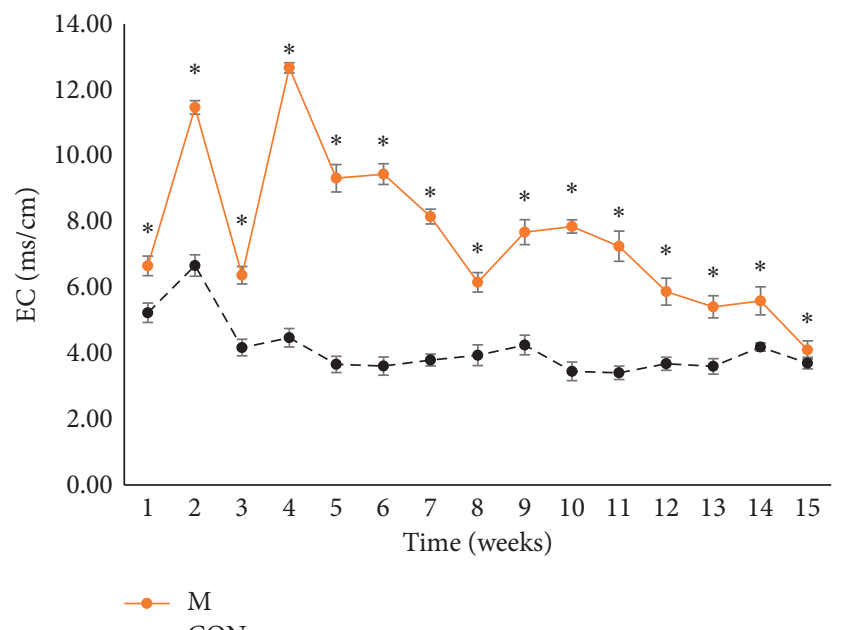

$-\bullet$ CON

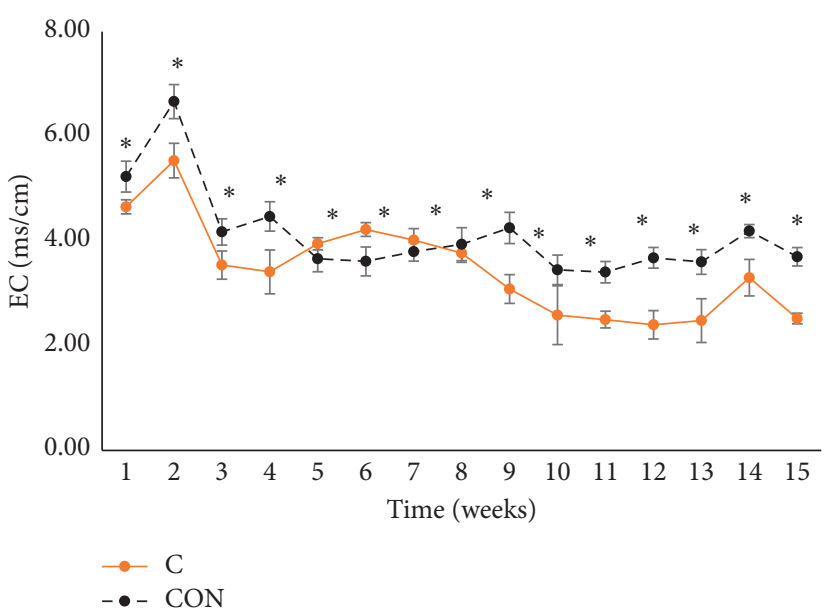

(b)

FIgURE 5: Continued. 


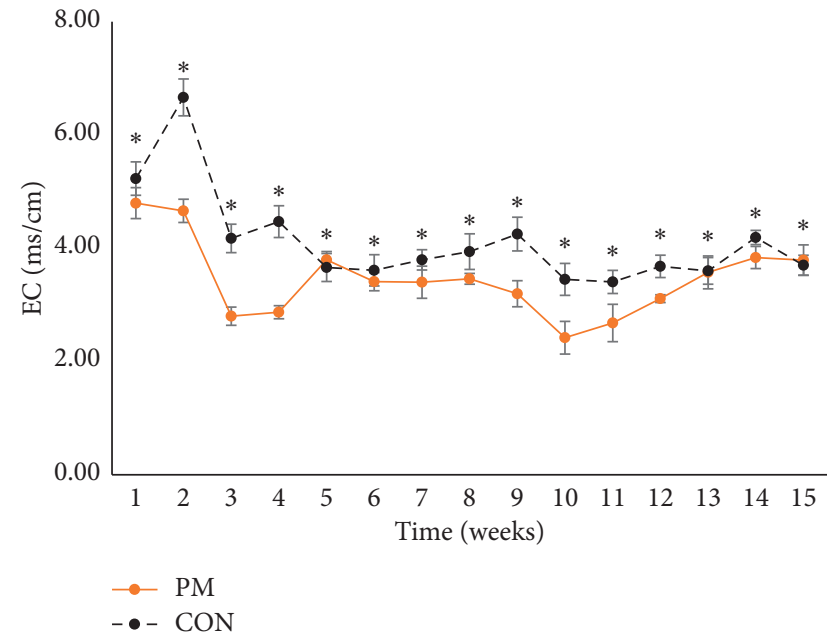

(c)

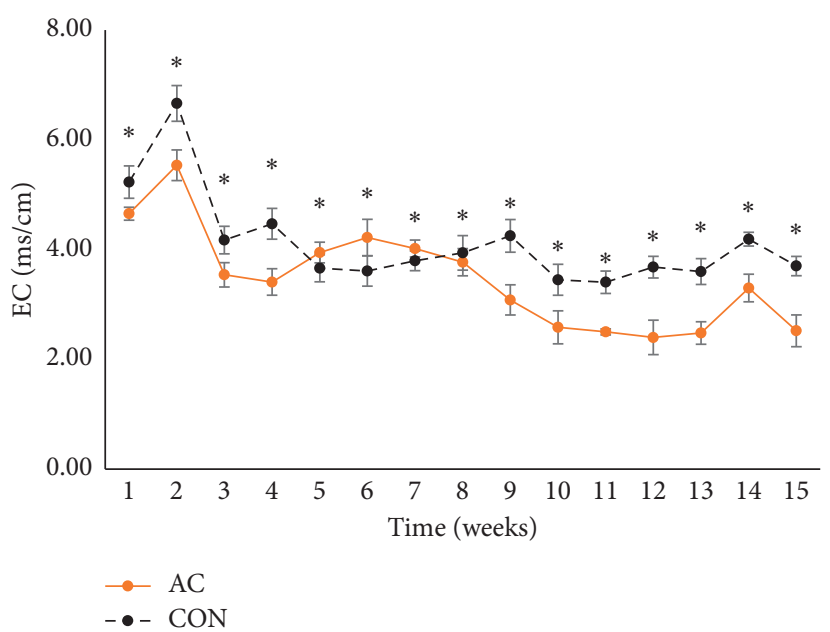

(d)

Figure 5: Soil EC values over 15 weeks of treatment; (a) molasses vs. control; (b) compost vs. control; (c) papermill sludge vs. control; and (d) activated carbon vs. control. M: molasses; C: plant compost; PM: papermill sludge; AC: activated carbon; and CON: control. (*) indicates that data for the treatment were significantly different $(p<0.05)$ from the control.

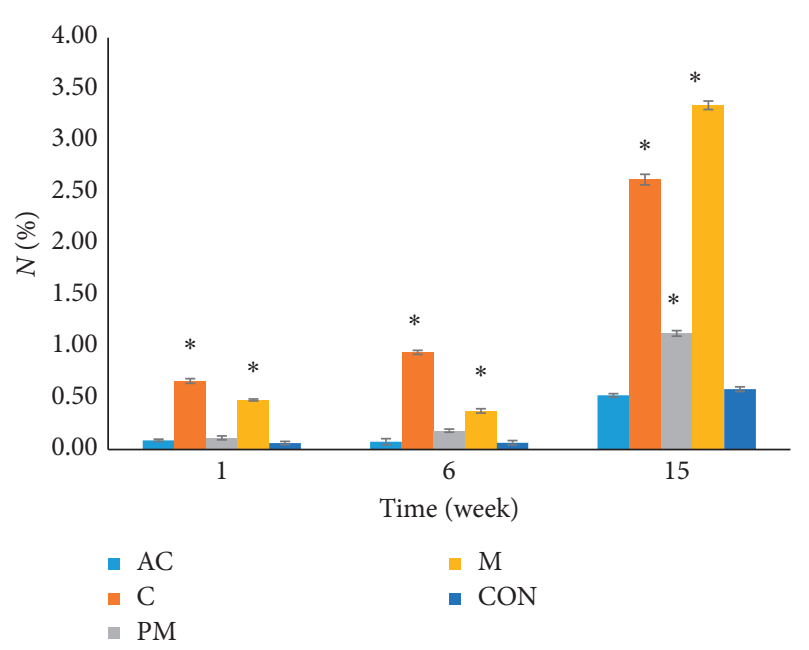

(a)

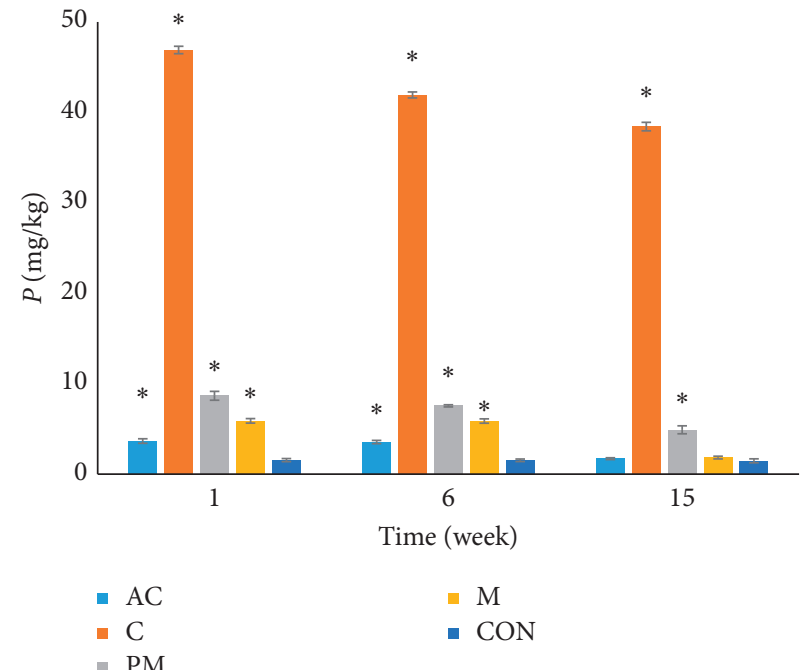

(b)

Figure 6: Continued. 


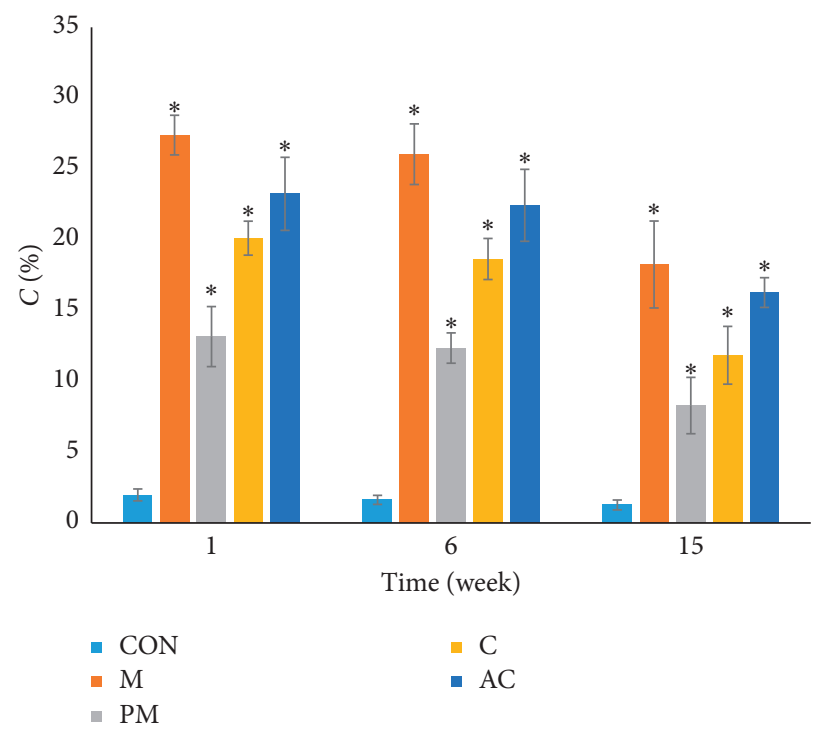

(c)

Figure 6: Changes in soil nutrient levels over 15 weeks as a function of treatment: (a) nitrogen; (b) phosphorus; and (c) organic carbon. M: molasses; C: plant compost; PM: papermill sludge; AC: activated carbon; and CON: control. $(*)$ indicates that data for the treatment were significantly different $(p<0.05)$ from the control.

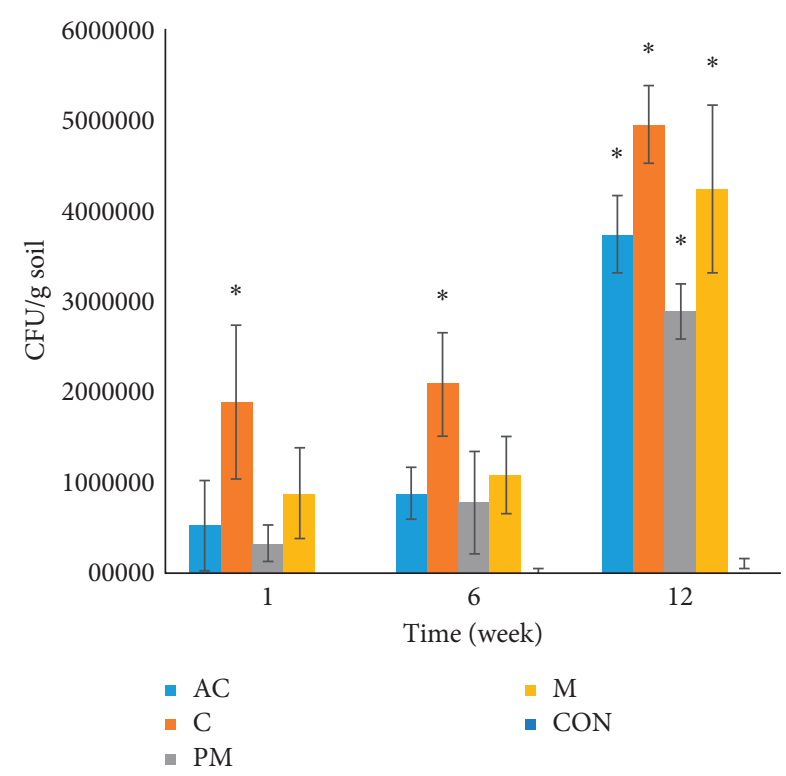

Figure 7: Total soil population bacterial counts over 15 weeks as a function of treatment. M: molasses; C: plant compost; PM: papermill sludge; AC: activated carbon; and CON: control. $(*)$ indicates that data for the treatment were significantly different $(p<0.05)$ from the control.

microbial oxidation. These results agree with the work of Riffaldi et al. [77] in a study on the bioremediation of hydrocarbon-contaminated soil.

3.4. Soil Bacteria. Populations of total culturable bacteria counts followed a consistent pattern over 15 weeks (Figure 7); bacterial populations increased for all treatments except the control. The compost and molasses treatments had the highest bacterial counts $\left(4.9 \times 10^{6}\right.$ and $4.2 \times 10^{6} \mathrm{CFU} /$ $\mathrm{g}$, respectively), and the untreated oil-contaminated soil had the lowest $\left(1 \times 10^{5} \mathrm{CFU} / \mathrm{g}\right)$.

Compost application can increase soil nutrient concentrations, biodegradable carbon supply, and bacterial numbers in soils. It can also improve soil physical properties such as water-holding capacity, which is essential for microbial proliferation. In a study by Wang et al. [8], compost application to diesel- and oil-affected soil increased TPH biodegradation, enhanced bacterial diversity, and increased total bacterial populations. In RDX-contaminated soil, Lamichhane et al. [45] found that soil bacterial densities in molasses-treated units were much greater than those without molasses and that dilute molasses was effective at enhancing hydrocarbon degradation.

\section{Conclusions}

The reported laboratory-scale study demonstrates that landfarming with appropriate amendments is effective for rapid removal of TPH from arid region soil containing weathered petroleum hydrocarbons. All amendments improved soil chemical and/or physical properties to some degree. Decompostion of TPH may be the result of combined biostimulation and bioaugmentation. It is suggested that cometabolism played a substantial role in TPH degradation.

The molasses treatment resulted in the highest percentage TPH and benzene removal; bacterial numbers were also the greatest in this treatment. The degradation constant (k) produced by a kinetic model also demonstrated the superior performance of the molasses over the other treatments. 
Local, noncontaminated soil was mixed with the oilcontaminated soil in order to simulate actual field-scale landfarming operations. Such dilution presumably rendered the affected soil less toxic to soil microorganisms, thus enhancing the rate of TPH and benzene degradation.

Based on the findings of the current study, it is possible to successfully conduct landfarming of aged petroleum wastes; however, it is recommended that common and inexpensive amendments such as molasses and plant compost be used when feasible.

\section{Data Availability}

Data are available through the author Kimiya Yousefi at k.yousefi90@gmail.com.

\section{Conflicts of Interest}

The authors have no conflicts of interest.

\section{Acknowledgments}

Support for graduate study from Shahid Bahonar University, Kerman, Iran, is gratefully acknowledged.

\section{References}

[1] J. Tang, X. Lu, Q. Sun, and W. Zhu, "Aging effect of petroleum hydrocarbons in soil under different attenuation conditions," Agriculture, Ecosystems \& Environment, vol. 149, pp. 109-117, 2012.

[2] F. I. Khan, T. Husain, and R. Hejazi, "An overview and analysis of site remediation technologies," Journal of Environmental Management, vol. 71, no. 2, pp. 95-122, 2004.

[3] P. Agamuthu, Y. S. Tan, and S. H. Fauziah, "Bioremediation of hydrocarbon contaminated soil using selected organic wastes," Procedia Environmental Sciences, vol. 18, pp. 694702, 2013.

[4] PHMSA (Pipeline and Hazardous Materials Safety Administration), Pipeline Incident 20 Year Trends, PHMSA, Washington, DC, USA, 2020, https://www.phmsa.dot.gov/ data-and-statistics/pipeline/pipeline-incident-20-year-trends.

[5] X. Li, Y. Du, G. Wu, Z. Li, H. Li, and H. Sui, "Solvent extraction for heavy crude oil removal from contaminated soils," Chemosphere, vol. 88, no. 2, pp. 245-249, 2012.

[6] Q.-r. Zhang, Q.-x. Zhou, L.-p. Ren, Y.-g. Zhu, and S.-1. Sun, "Ecological effects of crude oil residues on the functional diversity of soil microorganisms in three weed rhizospheres," Journal of Environmental Sciences, vol. 18, no. 6, pp. 11011106, 2006.

[7] A. Besalatpour, M. A. Hajabbasi, A. H. Khoshgoftarmanesh, and V. Dorostkar, "Landfarming process effects on biochemical properties of petroleum-contaminated soils," Soil and Sediment Contamination: An International Journal, vol. 20, no. 2, pp. 234-248, 2011.

[8] S.-Y. Wang, Y.-C. Kuo, A. Hong, Y.-M. Chang, and C.-M. Kao, "Bioremediation of diesel and lubricant oilcontaminated soils using enhanced landfarming system," Chemosphere, vol. 164, pp. 558-567, 2016.

[9] A. Thomé, C. Reginatto, I. Cecchin, and L. M. Colla, "Bioventing in a residual clayey soil contaminated with a blend of biodiesel and diesel oil," Journal of Environmental Engineering, vol. 140, no. 11, Article ID 06014005, 2014.
[10] F. Fernández-Luqueño, R. Marsch, D. Espinosa-Victoria et al., "Remediation of PAHs in a saline-alkaline soil amended with wastewater sludge and the effect on dynamics of C and N," Science of The Total Environment, vol. 402, no. 1, pp. 18-28, 2008.

[11] D. M. Brown, S. Okoro, J. van Gils et al., "Comparison of landfarming amendments to improve bioremediation of petroleum hydrocarbons in Niger Delta soils," Science of The Total Environment, vol. 596-597, pp. 284-292, 2017.

[12] M. E. Mancera-López, F. Esparza-García, B. Chávez-Gómez, R. Rodríguez-Vázquez, G. Saucedo-Castañeda, and J. BarreraCortés, "Bioremediation of an aged hydrocarbon-contaminated soil by a combined system of biostimulation-bioaugmentation with filamentous fungi," International Biodeterioration \& Biodegradation, vol. 61, no. 2, pp. 151-160, 2008.

[13] S. Abdulsalam, I. M. Bugaje, S. S. Adefila, and S. Ibrahim, "Comparison of biostimulation and bioaugmentation for remediation of soil contaminated with spent motor oil," International Journal of Environmental Science \& Technology, vol. 8, no. 1, pp. 187-194, 2011.

[14] D. Sarkar, M. Ferguson, R. Datta, and S. Birnbaum, "Bioremediation of petroleum hydrocarbons in contaminated soils: comparison of biosolids addition, carbon supplementation, and monitored natural attenuation," Environmental Pollution, vol. 136, no. 1, pp. 187-195, 2005.

[15] H. Y. Chien, C. M. Kao, J. K. Liu, K. Takagi, and R. Y. Surampalli, "Clean up of petroleum-hydrocarbon contaminated soils using enhanced bioremediation system: laboratory feasibility study," Journal of Environmental Engineering, vol. 136, no. 6, pp. 597-606, 2009.

[16] R. U. Ofoegbu, Y. O. Momoh, and I. L. Nwaogazie, "Bioremediation of crude oil contaminated soil using organic and inorganic fertilizers," Journal of Petroleum and Environmental Biotechnology, vol. 6, no. 1, 2015.

[17] G. Olawepo, C. Ogunkunle, O. Adebisi, and P. Fatoba, "Enhanced bioremediation of brass crude-oil (hydrocarbon), using cow dung and implication on microbial population," Pollution, vol. 4, no. 2, pp. 273-280, 2018.

[18] M. Tejada, M. Hernandez, and C. Garcia, "Soil restoration using composted plant residues: effects on soil properties," Soil and Tillage Research, vol. 102, no. 1, pp. 109-117, 2009.

[19] A. Tubeileh and G. Stephenson, "Suppressing verticillium dahliae through compost application," Current Plant Biology, vol. 22, Article ID 10048, 2019.

[20] P. Saengwilai, W. Meeinkuirt, T. Phusantisampan, and J. Pichtel, "Immobilization of cadmium in contaminated soil using organic amendments and its effects on rice growth performance," Exposure and Health, vol. 12, no. 2, pp. 295-306, 2019.

[21] W. Namkoong, E.-Y. Hwang, J.-S. Park, and J.-Y. Choi, "Bioremediation of diesel-contaminated soil with composting," Environmental Pollution, vol. 119, no. 1, pp. 23-31, 2002.

[22] I. M. Adekunle, "Bioremediation of soils contaminated with Nigerian petroleum products using composted municipal wastes," Bioremediation Journal, vol. 15, no. 4, pp. 230-241, 2011.

[23] W.-H. Chen, Y.-C. Lin, J.-H. Lin, P.-M. Yang, and S.-R. Jhang, "Treating odorous and nitrogenous compounds from waste composting by acidic chlorination followed by alkaline sulfurization," Environmental Engineering Science, vol. 31, no. 11, pp. 583-592, 2014.

[24] A. Battaglia, N. Calace, E. Nardi, B. M. Petronio, and M. Pietroletti, "Reduction of $\mathrm{Pb}$ and $\mathrm{Zn}$ bioavailable forms in 
metal polluted soils due to paper mill sludge addition," Bioresource Technology, vol. 98, no. 16, pp. 2993-2999, 2007.

[25] N. Calace, T. Campisi, A. Iacondini, M. Leoni, B. M. Petronio, and M. Pietroletti, "Metal-contaminated soil remediation by means of paper mill sludges addition: chemical and ecotoxicological evaluation," Environmental Pollution, vol. 136, no. 3, pp. 485-492, 2005.

[26] M. T. Rashid, D. Barry, and M. Goss, "Paper mill biosolids application to agricultural lands: benefits and environmental concerns with special reference to situation in Canada," Soil and Environment, vol. 25, no. 2, pp. 85-98, 2006.

[27] M. N. Al-Hadhrami, H. M. Lappin-Scott, and P. J. Fisher, "Effects of the addition of organic carbon sources on bacterial respiration and $n$-alkane biodegradation of Omani crude oil," Marine Pollution Bulletin, vol. 32, no. 4, pp. 351-357, 1996.

[28] R. Boopathy and J. Manning, "Surfactant-enhanced bioremediation of soil contaminated with 2,4,6-trinitrotoluene in soil slurry reactors," Water Environment Research, vol. 71, no. 1, pp. 119-124, 1999.

[29] P. Meynet, S. E. Hale, R. J. Davenport, G. Cornelissen, G. D. Breedveld, and D. Werner, "Effect of activated carbon amendment on bacterial community structure and functions in a PAH impacted urban soil," Environmental Science \& Technology, vol. 46, no. 9, pp. 5057-5066, 2012.

[30] P. R. Day, "Particle fractionation and particle-size analysis," Methods of Soil Analysis: Part 1 Physical and Mineralogical Properties, Including Statistics of Measurement and Sampling, vol. 9, pp. 545-567, American Society of Agronomy, Madison, WI, USA, 1965.

[31] R. B. Bradstreet, "Kjeldahl method for organic nitrogen," Analytical Chemistry, vol. 26, no. 1, pp. 185-187, 1954.

[32] S. R. Olsen and L. E. Sommers, Phosphorus in: Methods of Soil Analysis, part 2, Chemical and Microbiological Properties, A. L. Page, R. H. Miller, and D. R. Keeney, Eds., pp. 403-430, American Society of Agronomy, Madison, WI, USA, 2nd edition, 1982.

[33] D. A. Storer, "A simple high sample volume ashing procedure for determination of soil organic matter," Communications in Soil Science and Plant Analysis, vol. 15, no. 7, pp. 759-772, 1984.

[34] A. P. Schwab, J. Su, S. Wetzel, S. Pekarek, and M. K. Banks, "Extraction of petroleum hydrocarbons from soil by mechanical shaking," Environmental Science \& Technology, vol. 33, no. 11, pp. 1940-1945, 1999.

[35] J. Šíma, M. Pazderník, J. Tř́íska, and L. Svoboda, "Degradation of surface-active compounds in a constructed wetland determined using high performance liquid chromatography and extraction spectrophotometry," Journal of Environmental Science and Health, Part A, vol. 48, no. 5, pp. 559-567, 2013.

[36] D. A. Turner and J. V. Goodpaster, "The effects of microbial degradation on ignitable liquids," Analytical and Bioanalytical Chemistry, vol. 394, no. 1, pp. 363-371, 2009.

[37] J. G. Cappuccino and N. Sherman, Experiment 53: Microbial Populations in Soil: Enumeration. Microbiology, A Laboratory Manual. Pearson, New York, USA, 1998.

[38] United Molasses Company (UMC), No Date, By Courtesy of the Technology Division of Crompton and Knowles Corporation, London, UK Mahwah, NJ, USA.

[39] M. Nikolopoulou and N. Kalogerakis, "Enhanced bioremediation of crude oil utilizing lipophilic fertilizers combined with biosurfactants and molasses," Marine Pollution Bulletin, vol. 56, no. 11, pp. 1855-1861, 2008.
[40] Y. T. He and C. Su, "Use of additives in bioremediation of contaminated groundwater and soil," Advances in Bioremediation of Wastewater and Polluted Soil, vol. 145, 2015.

[41] G. Khayati and M. Barati, "Bioremediation of petroleum hydrocarbon contaminated soil: optimization strategy using Taguchi design of experimental (DOE) methodology," Environmental Processes, vol. 4, no. 2, pp. 451-461, 2017.

[42] R. Boopathy, S. Shields, and S. Nunna, "Biodegradation of crude oil from the BP oil spill in the marsh sediments of southeast Louisiana, USA," Applied Biochemistry and Biotechnology, vol. 167, no. 6, pp. 1560-1568, 2012.

[43] T. T. Tsai, C. M. Kao, R. Y. Surampalli, and H. Y. Chien, "Enhanced bioremediation of fuel-oil contaminated soils: laboratory feasibility study," Journal of Environmental Engineering, vol. 135, no. 9, pp. 845-853, 2009.

[44] M. Soleimani, M. Farhoudi, and J. H. Christensen, "Chemometric assessment of enhanced bioremediation of oil contaminated soils," Journal of Hazardous Materials, vol. 254255, pp. 372-381, 2013.

[45] K. M. Lamichhane, R. W. Babcock Jr., S. J. Turnbull, and S. Schenck, "Molasses enhanced phyto and bioremediation treatability study of explosives contaminated Hawaiian soils," Journal of Hazardous Materials, vol. 243, pp. 334-339, 2012.

[46] U.S. Environmental Protection Agency, Abstracts of Remediation Case Studies, vol. 4, U.S. Environmental Protection Agency, Washington, DC, USA, 2000.

[47] V. Prakash, S. Saxena, A. Sharma, S. Singh, and S. K. Singh, "Treatment of oil sludge contamination by composting," Journal of Bioremediation and Biodegradation, vol. 6, no. 3, p. 1, 2015.

[48] J. A. Park, J. M. Hur, B. K. Jang, and B. S. Son, "Evaluation of compost addition and its effect on biodegradation of diesel-oil in contaminated soil composting," Journal of Industrial and Engineering Chemistry, vol. 7, no. 3, pp. 127-136, 2001.

[49] E. Vasconcelos and F. Cabral, "Use and environmental implications of pulp-mill sludge as an organic fertilizer," Environmental Pollution, vol. 80, no. 2, pp. 159-162, 1993.

[50] T. Kuokkanen, H. Nurmesniemi, R. Pöykiö, K. Kujala, J. Kaakinen, and M. Kuokkanen, "Chemical and leaching properties of paper mill sludge," Chemical Speciation \& Bioavailability, vol. 20, no. 2, pp. 111-122, 2008.

[51] J. J. Camberato, B. Gagnon, D. A. Angers, M. H. Chantigny, and W. L. Pan, "Pulp and paper mill by-products as soil amendments and plant nutrient sources," Canadian Journal of Soil Science, vol. 86, no. 4, pp. 641-653, 2006.

[52] Z. Han, B. Sani, J. Akkanen et al., "A critical evaluation of magnetic activated carbon's potential for the remediation of sediment impacted by polycyclic aromatic hydrocarbons," Journal of Hazardous Materials, vol. 286, pp. 41-47, 2015.

[53] P. J. Alvarez and T. M. Vogel, "Substrate interactions of benzene, toluene, and para-xylene during microbial degradation by pure cultures and mixed culture aquifer slurries," Applied and Environmental Microbiology, vol. 57, no. 10, pp. 2981-2985, 1991.

[54] Y. Zhang, Y.-G. Zhu, S. Houot, M. Qiao, N. Nunan, and P. Garnier, "Remediation of polycyclic aromatic hydrocarbon (PAH) contaminated soil through composting with fresh organic wastes," Environmental Science and Pollution Research, vol. 18, no. 9, pp. 1574-1584, 2011.

[55] NIST National Institute of Standards and Technology, Hexadecane. 2018, https://webbook.nist.gov/cgi/cbook.cgi? ID $=$ C544763\&Units $=$ SI\&Mask $=2 F F$.

[56] NIST National Institute of Standards and Technology, Eicosane. https://webbook.nist.gov/cgi/cbook.cgi?ID=C112958\&Mask=80. 
[57] A. Geach, "Infrared analysis as a tool for assessing degradation in used engine lubricants," Wearcheck Technical Bulletin, vol. 2, 1996.

[58] A. N. Kadam and M. D. Zingde, "Infrared-spectroscopy analysis of used crankcase oil," Resind legal, vol. 30, no. 4, pp. 382-385, 1985.

[59] R. Abdullah, C. Ishak, W. Kadir, and R. Bakar, "Characterization and feasibility assessment of recycled paper mill sludges for land application in relation to the environment," International Journal of Environmental Research and Public Health, vol. 12, no. 8, pp. 9314-9329, 2015.

[60] M. A. Torkashvand, "The effect of paper mill sludge on chemical properties of acid soil," African Journal of. Agricultural Research, vol. 5, no. 22, pp. 3082-3087, 2010.

[61] Desotec, Carbonology. 2020, https://www.desotec.com/en/ carbonology/carbonology-academy/activated-carbon-phacidity.

[62] IGCL(Indo German Carbons Limited), Activated Carbon. 2020, https://www.igcl.com/php/activated_carbon.php.

[63] M. A. Clarke, "Syrups," in Encyclopedia of Food Sciences and Nutrition, Johns Hopkins University, Baltimore, MD, USA, 2003, https://www.sciencedirect.com/topics/food-science/ molasses, 2nd edition.

[64] A. F. Wick, N. W. Haus, B. F. Sukkariyah, K. C. Haering, and W. L. Daniels, Remediation of PAH-Contaminated Soils and Sediments: A Literature Review, CSES Department, Internal Research Document, Blacksburg, VA, USA, 2011.

[65] R. M. Maier and T. J. Gentry, "Microorganisms and organic pollutants," in Environmental Microbiology, pp. 377-413, Academic Press, New York, USA, 2015.

[66] T. Higa and N. Chinen, EM Treatments of Odor, Waste Water, and Environment Problems, University of Ryukyus, Okinawa, Japan, 1998.

[67] I. M. Cozzarelli, R. P. Eganhouse, and M. J. Baedecker, "Transformation of monoaromatic hydrocarbons to organic acids in anoxic groundwater environment," Environmental Geology and Water Sciences, vol. 16, no. 2, pp. 135-141, 1990.

[68] K. I. Ekpeghere, B.-H. Kim, H.-S. Son, K.-S. Whang, H.-S. Kim, and S.-C. Koh, "Functions of effective microorganisms in bioremediation of the contaminated harbor sediments," Journal of Environmental Science and Health, Part A, vol. 47, no. 1, pp. 44-53, 2012.

[69] D. León-Lorenzana, S. Arit, L. Delgado-Balbuena et al., "Soil salinity controls relative abundance of specific bacterial groups involved in the decomposition of maize plant residues," Frontiers in Ecology and Evolution, vol. 6, p. 51, 2018.

[70] E. M. Morrissey, J. L. Gillespie, J. C. Morina, and R. B. Franklin, "Salinity affects microbial activity and soil organic matter content in tidal wetlands," Global Change Biology, vol. 20, no. 4, pp. 1351-1362, 2014.

[71] S. Tripathi, S. Kumari, A. Chakraborty, A. Gupta, K. Chakrabarti, and B. K. Bandyapadhyay, "Microbial biomass and its activities in salt-affected coastal soils," Biology and Fertility of Soils, vol. 42, no. 3, pp. 273-277, 2006.

[72] M. J. Ayotamuno, R. B. Kogbara, S. O. T. Ogaji, and S. D. Probert, "Bioremediation of a crude-oil polluted agricultural-soil at Port Harcourt, Nigeria," Applied Energy, vol. 83, no. 11, pp. 1249-1257, 2006.

[73] R. Ostertag, "Foliar nitrogen and phosphorus accumulation responses after fertilization: an example from nutrient-limited Hawaiian forests," Plant Soil, vol. 334, no. 1-2, pp. 85-98, 2010.

[74] F. A. Orji, A. A. Ibiene, and E. N. Dike, "Laboratory scale bioremediation of petroleum hydrocarbon-polluted mangrove swamps in the Niger Delta using cow dung," The
Malaysian Journal of Microbiology, vol. 8, no. 4, pp. 219-228, 2012.

[75] L. O. Odokuma and A. A. Dickson, "Bioremediation of a crude oil polluted tropical rain forest soil," Global Journal of Environmental Science and Management, vol. 2, no. 1, pp. 29-40, 2003.

[76] M.-S. Chou, Y.-F. Chang, and H.-T. Perng, "Treatment of propylene glycol monomethyl ether acetate in air streams by a biofilter packed with fern chips," Journal of the Air \& Waste Management Association, vol. 58, no. 12, pp. 1590-1597, 2008.

[77] R. Riffaldi, R. Levi-Minzi, R. Cardelli, S. Palumbo, and A. Saviozzi, "Soil biological activities in monitoring the bioremediation of diesel oil-contaminated soil," Water, Air, \& Soil Pollution, vol. 170, no. 1-4, pp. 3-15, 2006. 